\title{
The South Sea Oracle
}

Author(s): E. J. E. Swayne

Source: The Geographical Journal, Vol. 50, No. 6 (Dec., 1917), pp. 466-467

Published by: geographicalj

Stable URL: http://www.jstor.org/stable/1780390

Accessed: 19-04-2016 09:02 UTC

\section{Your use of the JSTOR archive indicates your acceptance of the Terms \& Conditions of Use, available at}

http://about.jstor.org/terms

JSTOR is a not-for-profit service that helps scholars, researchers, and students discover, use, and build upon a wide range of content in a trusted digital archive. We use information technology and tools to increase productivity and facilitate new forms of scholarship. For more information about JSTOR, please contact support@jstor.org.

The Royal Geographical Society (with the Institute of British Geographers), Wiley are collaborating with JSTOR to digitize, preserve and extend access to The Geographical Journal 
them, essentially English. ... Everything he had to do, whether in exploration or soldiering, he did supremely well, but without parade. He has rounded off a full and most honourable life with the kind of death which was a fitting close to such a record. Perhaps he had achieved both of his ambitions, for in the long sacrifice and endurance of the great war he scaled higher peaks than Everest."

\section{Brigadier-General Malcolm Peake, C.M.G., R.A.}

We record with great regret the death in action on August 27 of BrigadierGeneral Malcolm Peake, C.M.G., R.A., who had been a Fellow of the Society for thirteen years. He had passed much of his service with the Egyptian army, taking part in the Dongola Expedition of 1896 and the Nile Expedition of 1898 , and commanding the Egyptian artillery at the battles of Atbara and Omdurman. In 1899 he was sent in command of the expedition to clear the sudd from the upper reaches of the White Nile, and succeeded in opening the river for navigation, for which service he was given the C.M.G. During the first two years of the war he was engaged in organizing the artillery of the new armies, but in April 1916 went to France in command of the artillery of a division, being promoted later to command the artillery of a corps.

\section{Captain J. H. Miller.}

We regret to record the death of Captain J. H. Miller from blackwater fever in Alexandria. Although Captain Miller was only thirty-four years of age, he had had very considerable experience in many parts of the world, for since 1905 he had been travelling almost continually. His main object was the search for big game, yet he did much besides; he was a keen observer and collected many specimens for scientific institutions. After a summer spent in Iceland he joined Mr. Douglas Carruthers in Syria in 1905, and made large collections of birds and mammals in the Syrian desert and at Petra. In 1906 he was hunting in the interior of Asia Minor. In 1908 he travelled across Siberia and Turkestan, hunting in the Altai and the Tian Shan Mountains. In 1910-11, in company with Messrs. Carruthers and Price, he took part in an expedition, extending over twenty months, in Mongolia and Turkestan. He collected many interesting zoological specimens on this journey, and formed a remarkable collection of the big game of Central Asia. In I9I 3 he visited the Red Sea Province, and in the winter of $1913-14$ he was hunting with Mr. P. H. Thomas in Southern Abyssinia on the Somali borderlands. His collection included many notable trophies, and he was considered a very fine shot. One of the original Expeditionary Force in France, he was wounded in the battle of the Marne. On recovery he was attached to the Egyptian army, and was in charge at Kajo Kaji, in the Mongalla Province. Even here, in spite of heavy duties, he started to work on the ornithology of the surrounding country, and made great plans for the future. While on leave in Alexandria he suddenly developed blackwater fever and died on August 26.

\section{CORRESPONDENCE}

\section{The South Sea Oracle.}

IN the interesting discussion on Easter Island I find on p. 344 of the Geographical Journal an account of a custom (taken from Melville's 'Typee') where the priests whisper into the ears of an idol-god and receive oracles that they 
then communicate to the people. The accounts of the slaughter of the Spaniards in the North of British Honduras by the Santa Cruz Indians describe a similar proceeding. The chiefs (who appear to have also been the priests) certainly consulted the idol, whispering into its ear, and then giving forth the oracle.

Obsidian blades sharp as razors are very commonly found in British Honduras, but whence they get the jade for their carved figures has not been ascertained.

Pcronne, 5 November 1917 .

E. T. E. Swayne.

\section{GEOGRAPHICAL LITERATURE: ADDITIONS TO THE LIBRARY. Edward Heawood, Librarian, R.G.S.}

For list of abbreviations see Fanuary number.

\section{EUROPE}

Alps-Orography. Z.G.E. Berlin (1916) : 602-623, 675-687.

Machatschek.

Verebnungsflächen und junge Krustenbewegungen im alpinen Gebirgssystem. Von Fritz Machatschek.

Austria-Dalmatia-Italians. Riv. G. Italiana 24 (19I7): I32-I47. Dainelli. Quanti sieno gli Italiani in Dalmazia. By Giotto Dainelli.

The author analyses the official returns, and comes to the conclusion that they greatly under-rate the number of Italians in Dalmatia.

Balkan Peninsula-Historical. B.R.S.G. Italiana, Ser. V., 6 (1917) : 401-435.

Ricchieri.

Il fato geografico nella storia della penisola balcanica. By Giuseppe Ricchieri. Sketch-maps.

Balkans-Nationality.

Seton-Watson.

The rise of nationality in the Balkans. By Dr. R. W. Seton-Watson. London : Constable \& Co., 1917. Size $8 \frac{1}{2} \times 5 \frac{1}{2}$, pp. viii. and 308. Maps. Price Ios. $6 d$. net. Presented.

Belgium-Antwerp.

Antwerpen. Von K. Kretschmer.

Bosphorus and Dardanelles-Political.

Kretschmer.

The Bosphorus and Dardanelles. By Dr. Coleman Phillipson and

Noel Buxton. London : Stevens \& Haynes, 1917. Size Io $\times 6$, pp. xvi. and 264.

Price 12s. 6d. net. Presented.

Carpathians.

G. Rev. 3 (1917) : 417-437.

Martonne.

The Carpathians: Physiographic features controlling human geography. By

Emmanuel de Martonne. Maps, Sketch-maps and Illustrations.

Central Europe-Waterways. G.Z. 23(1917): 62-78.

Hennig.

Das mitteleuropaïsche Binnenschiffahrtsnetz und die Möglichkeit seiner Ausges-

taltung nach dem Kriege. Von Richard Hennig.

Europe-Communications. G.Z. 23 (1917) : I-9.

Das verkehrsgeographische Grundproblem des Weltkrieges. Von Arthur Dix. Sketch-map.

Europe-Historical-Cassiterides. G.Z. 23 (1917) : 216-220.

Die Lage der Zinneninseln des Altertums. Von W. J. Beckers.

Europe-Political. Riv. Coloniale I2 (1917): 237-249, 339-36o.

Le basi nazionali della Nuova Europa. By A. D'Alia. Map.

Europe-Political.

British foreign policy in Europe to the end of the nineteenth century x. and 440. Price 6s, net. Presented. 